\title{
The NESA transoral thyroidectomy at a crossroad
}

\author{
Michael Stark, Tahar Benhidjeb \\ The New European Surgical Academy (NESA), Berlin, Germany \\ Correspondence to: Michael Stark. The New European Surgical Academy (NESA), Unter den Linden 21, 10117 Berlin, Germany. \\ Email: mstark@nesacademy.org. \\ Comment on: Russell JO, Sahli ZT, Shaear M, et al. Transoral thyroid and parathyroid surgery via the vestibular approach-a 2020 update. Gland Surg \\ 2020;9:409-16.
}

Submitted Jun 08, 2020. Accepted for publication Jul 19, 2020.

doi: 10.21037 /gs-20-549

View this article at: http://dx.doi.org/10.21037/gs-20-549

We read with great interest the excellent article "Transoral thyroid and parathyroid surgery via the vestibular approach - a 2020 update" by Jonathon O. Russell et al. (1).

We feel privileged that this novel approach which we named Transoral Video-Assisted Thyroidectomy (TOVAT) which has been initiated by the New European Surgical Academy (NESA) in $2007(2,3)$ got such an extended interest and distribution.

Certainly, this approach promises an improvement to the 140 years old Kocher's cervical approach, but like any new surgical approach, the Trans Oral approach requires knowledge and learning curve. The surgeon is expected to have extensive experience in both, thyroid and endoscopic surgery. Furthermore, we should keep in mind that this approach already yielded complications that are inherent to the method itself as mentioned by Russell et al. (1) Therefore, it is legitimate to ask if the transoral thyroidectomy is indeed an improvement to the traditional cervical approach, which is highly standardized and safe procedure with low morbidity. We have to admit that the transoral thyroidectomy does not fulfil at the moment the well-established criteria and standards and it is even an ethical dilemma when offering this approach to the patient. Aesthetics is certainly an important issue but should never be at the expense of safety.

We certainly believe that our approach should be realized but not before the development of appropriate simulators, designed instruments and surgical (pre-clinical) workshops.

\section{Acknowledgments}

Funding: None.

\section{Footnote}

Provenance and Peer Review: This article was a free submission to the journal, Gland Surgery. The article did not undergo external peer review.

Conflicts of Interest: Both authors have completed the ICMJE uniform disclosure form (available at http://dx.doi. org/10.21037/gs-20-549). The authors have no conflicts of interest to declare.

Ethical Statement: The authors are accountable for all aspects of the work in ensuring that questions related to the accuracy or integrity of any part of the work are appropriately investigated and resolved.

Open Access Statement: This is an Open Access article distributed in accordance with the Creative Commons Attribution-NonCommercial-NoDerivs 4.0 International License (CC BY-NC-ND 4.0), which permits the noncommercial replication and distribution of the article with the strict proviso that no changes or edits are made and the original work is properly cited (including links to both the formal publication through the relevant DOI and the license). See: https://creativecommons.org/licenses/by-nc-nd/4.0/.

\section{References}

1. Russell JO, Sahli ZT, Shaear M, et al. Transoral thyroid and parathyroid surgery via the vestibular approach-a 2020 update. Gland Surg 2020;9:409-16.

2. Benhidjeb T, Wilhelm T, Harlaar J, et al. Natural orifice surgery on thyroid gland: totally transoral video-assisted 
thyroidectomy (TOVAT): report of first experimental results of a new surgical method. Surg Endosc 2009;23:1119-20.

Cite this article as: Stark M, Benhidjeb T. The NESA transoral thyroidectomy at a crossroad. Gland Surg 2020;9(5):11701171. doi: $10.21037 /$ gs-20-549
3. Benhidjeb T, Harlaar J, Kerver A, et al. Transoral endoscopic thyroidectomy: Part 2: Surgical technique. Chirurg 2010;81:134-8. 